\title{
Dancing with Jesus as the incarnate male 'missionary' conversant: A homeless group's reading of John 4 in dealing with gender-based violence
}

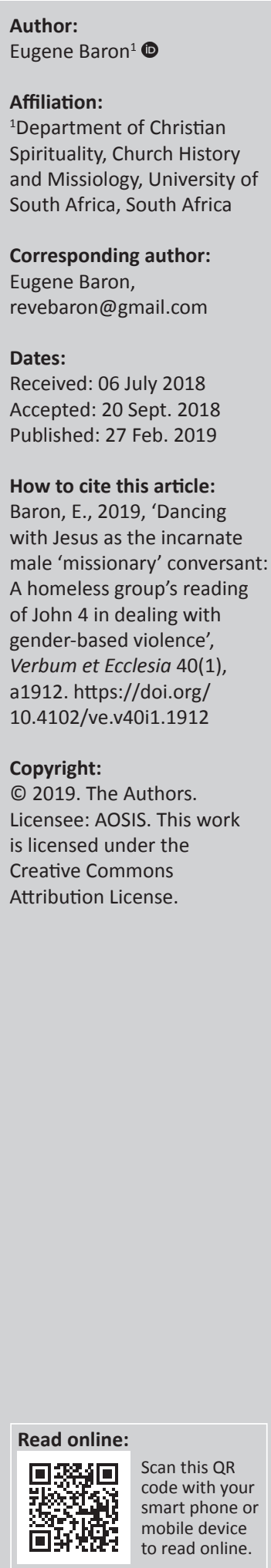

In this article, the metaphor of dancing is used to discuss the skewed gender relations in society as a result of the various interpretations available in terms of the narrative of Jesus and the Samaritan woman (Jn 4). The question explored is the following: how scholarly interpreters of the Bible and the homeless people describe this 'dancing', that is, the human movements between the male and female conversation partners? The author uses the 'woman-friendly' interpretations of various theologians on the John 4:1-42 narrative and juxtaposes it against other theologians' interpretations. Furthermore, the author discusses how a homeless group in the City of Tshwane reflects on and interprets the text. The article builds on the premise that biblical texts like John 4:1-42 - which are interpreted in a way that sustains patriarchy - serve as the cause for gender-based violence. Therefore, although the article does not refer directly to the issue of gender-based violence, it is contributing to 'woman-friendly' interpretations of Biblical texts to counter patriarchal tendencies in society.

Intradisciplinary and/or interdisciplinary implications: This is interdisciplinary study as it integrates gender-based violence in the field of sociology, public theology, feminist ethics with missiology. It is also integrating the field of biblical hermeneutics with missiology in terms of a specific biblical text namely Jn. 4 that is analysed.

\section{Introduction}

In 2016, Karim and Baxter (2016) reported that 'Gender-based violence is regarded as a major problem in South African (SA) communities, and is seen to be exacerbated by unemployment, poverty and alcohol abuse'. It is also relatively overemphasised that the root causes of genderbased violence do not only include 'unemployment, poverty and alcohol abuse', but also the prevalence of patriarchy in South Africa. ${ }^{1}$ In similar vein, Karim and Baxter (2016) report,

Despite being a fundamental violation of women's human rights, gender-based violence (GBV) is often rooted in socially accepted gender inequality and discrimination and is therefore condoned. The power imbalances between men and women, at both societal and individual relationship levels, are often established during adolescence. (p. 1151)

The problem of patriarchy can be taken further to ask the following question: how does the church contribute to patriarchy through the skewed gender relations that exist; socially accepted gender stereotypes, inequality and discrimination that sustain and perpetuate gender-based violence? Pillay (2015:558) provides a response when stating that the (institutional) church is legitimising patriarchy as the 'natural order of things'. This is so 'natural' that Landman (2006) responds to one of the contested reformed confessions of the Uniting Reformed Church in Southern Africa (URCSA), which is said to advocate among others, justice - the injustice by the church's confession in terms of the articulation of the Belhar Confession. Landman (2006) questions in her article 'Can justice be embodied in sexist language? A challenge to the Confession of Belhar' why the very confession that is speaking out, and confessing God as just, was not written in inclusive language, but rather embodied in sexist language.

It is the church which, through its worship and ideology, ${ }^{2}$ allows women to perceive themselves as subordinate to men. This allows members of the church to not only perceive this skewed relationship between men and women as 'natural' but also to allow it to often become the 'lived experience' 1.See the work of Miranda Pillay in which she lists the various contributions that deal with the issue of gender-based violence, but
particularly the focus on the root cause of patriarchy of our (Christian) faith. She refers in a footnote to such contributions: Ackermann particularly the focus on the root cause of patriarchy of our (Christian) faith. She refers in a footr
$(2003,2005: 385-395,2006: 221-242)$; Pillay (2003:108-121, 2005:441-455, 2007:209-226).

2.Ideology is used in this contribution in a more neutral sense. 
in their respective families and homes. Pillay (2015:563) refers to the role of the church in sustaining a patriarchal environment. This, as Pillay (2015:563) argues, is the reason for gender-based violence. Pillay presents in her work a case study of a 'Christian' student who describes his lived experience of gender-based violence that took place right under his nose - in his Christian family home. The student reported an incident where he witnessed his Christian father abusing his mother. He also recalls his mother being silent on the matter. The experience of the student is captured by Pillay as follows as she describes this incident against the background of her assessment of the destructive role and negative contribution of the church in gender-based violence: '... the wife of an abused husband would rather keep silent, as if this would be a virtue of a virtuous, dutiful, grateful wife'. She frames this as a result of the (institutional) church when it colludes with culture and portrays such silence of women as 'a good value to be embodied'. She argues that in most church cultures, women are virtuous, as long as they remain in 'silence' and 'subservient' to their abusive male partners, because this is said to be a 'biblical requirement' (Pillay 2015:563).

It is therefore safe to say that the way, in most instances, biblical texts are used to promote oppression and to dehumanise and marginalise certain members of society is not new, especially the oppression of women in society. How can South Africans ever forget the way in which biblical texts were used as an instrument to enforce the evil system of apartheid? Though biblical texts and church confessions are used to engage the injustices of the past, it was not equally applied and used for the emancipation of women. ${ }^{3}$

The importance of reading and interpreting biblical texts through a hermeneutical lens that is liberating women from the perception that they are unequal and subordinate to men is crucial, because the way in which the church allows people to 'see' women through a biblical text will either contribute to the increasing number of violent crimes against women, or will assist members of society to value and appreciate women as equal contributors to the welfare of our societies and decrease the violent acts against them. Pillay (2013) explains:

Feminism recognises patriarchy as a system of oppressive power that through its institutionalisation masquerades as being beneficial to the oppressed. It's a system that has throughout the ages been posited as a god ordained holy hierarchy - sanctified by certain biblical passages. (p. 64)

Therefore, as Pillay (2013:55) suggests, if the church is to take a stand against gender-based violence, it should 'confront the patriarchal orientation of much of biblical texts'.

The aim of this article is indeed to showcase such tensions in the interpretation of the John 4 narrative. Interpreters of this text often portray the Samaritan woman as unequal to her male counterpart. The author will use the metaphor of the act

3.See, in particular, my reference to the academic contribution of Landman (2006) on the sexist language of the Belhar confession. of 'dancing' to describe the 'oscillation' between the role, status and position of the woman and the male Jesus by choreographers ${ }^{4}$ of the text. Let me therefore commence with a brief explanation of dance according to Wikipedia and explain subsequently how it will be used in this article. Dancing can be described as:

... a performing art form consisting of purposefully selected sequences of human movement. This movement has aesthetic and symbolic value, and is acknowledged as dance by performers and observers within a particular culture. Dance can be characterised and described by its choreography, by its repertoire of movement, or by its historical period or place of origin. (Wikipedia 2018)

The dance metaphor in John 4 will act as a suitable metaphor as it will try to best describe how interpreters of this narrative refer to the movements between the incarnate male embodiment of Jesus, and the Samaritan woman at the well, as it is done by what the author will refer to as the 'choreographers' of the text - in other words, those who construct through their interpretation the 'human movements'. To the ordinary reader, the text may seem quite straightforward. However, the 'choreographers' of this biblical text control the overall rhetorical effect that the text might have on its readers. The one who is dancing ${ }^{5}$ with Jesus is the Samaritan woman. How do interpreters of the narrative describe the 'dance'; the movements between the two in terms of how they comment on the respective roles, status and the position of each 'dancing partner'? The interpreters of this narrative do not, in any way, present the characters as 'static' - the characters are constantly 'moving' in the direction that the 'choreographers' (the interpreters) wish. The 'observers' of the dance will be those who make sense of the narrative by the interpretation presented by the 'choreographers', who are also known as the various interpreters of this text. The text, in this case also the 'dance' between the male and female characters in the John 4 narrative, is a construction by those who interpret the text, and this is possibly ${ }^{6}$ how communities will also view the role, status and position of both genders in society. This is an important part in the broader discussion on gender-based violence in society - in terms of the diverse interpretations of a biblical text such as John 4 .

The question that will be explored is the following: how do theologians and the homeless group (choreographers) describe this 'dancing', the human movements, in terms of the role, the status and the position in the conversation between the male and female conversation partners in the John 4 narrative? In most cases, it is male theologians who are the 'choreographers' of this text, explaining the movements, the sequence of the steps and indeed the role, the status and position ascribed to both characters in the text. As a male and a reformed theologian, I am sensitive to the overall aesthetic

4.Choreographers according to the South African Concise Oxford Dictionary (207:203) are those that would 'design' the 'sequences' and 'steps' of the dance movements.

5.This is how the author wishes to reflect on the movements between the two (male and female) conversation partners.

6.I prefer the word 'possibly', as this article is only discussing the text from the perspective of interpreters of the text, and not its reception (this would have to take various other constructs into consideration). 
performance of the 'dance' and interested in the fair and equal opportunity for both 'dancers' to 'perform' (well) in terms of the choreographers' interpretation and presentation of this biblical narrative. I am of the view that it is often the 'choreographer ${ }^{\prime 7}$ who is regarded as the main character playing the leading role, who determines what status or position is ascribed to the two, respectively, from which perspective to view the dance, and who will follow whose cue between the male and female characters.

Therefore, this academic contribution will focus on the way the reading and interpretation of biblical texts can contribute to the violent behaviour of men against women. In the interpretation of John 4, but also other biblical texts where women are narrated, interpreters of such texts should also aim to recognise and promote the full humanity of both male and female characters.

\section{The contextual Bible study methodology}

In terms of soliciting the interpretations of a homeless group regarding the John 4 narrative, I used the Contextual Bible Study (CBS) approach and method as developed by West (1993:11-12). This method was suitable as it allows the homeless people to read the Bible contextually from the perspective of the South African context, the perspective of the 'poor and the oppressed', but also to read the text 'in the community with others, particularly with those from contexts different from their own'. Furthermore, it allows the homeless people to read and reflect on the text 'critically' and in a way that will lead to 'individual and social transformation'. The article is structured in such a way that it follows strictly the methodology of West - it focuses not only on the theologians' interpretations of the text, but also the ordinary (a homeless group, in this case) reader's perspective of the biblical text.

In following West's approach, I presented the biblical text to a heterogeneous group (male and female participants) of homeless people who are based in the City of Tshwane, at the facilities of the Tshwane Leadership Foundation (TLF). The group was divided into three smaller groups of approximately six participants in each. The participants were given an opportunity to read through the text (Jn 4:1-42), reflect on it and then individually respond to four questions that were posed:

- How does the text help us to deal with gender-based violence?

- What is the problem in the text?

- What is the text about?

- Who are the characters and what role does each play in the narrative?

These questions were open-ended to allow the focus groups to explore, and for the researchers to gather information that result in a deeper reflection on the biblical text by the participants and how it relates to their own 'lived reality' and context - which also include experiences of genderbased violence. The questions also specifically focused on how the homeless group reflects on the 'movements' in terms of the role, the status and the position of both Jesus, as a male, and the Samaritan woman in the narrative. I collated all the responses, and I discuss the responses in one of the sections below.

\section{Theological dance}

In this section, the author will specifically compare the responses from theological scholars, and how they respond to the 'dance' of the 'human movements' in the text. It is important to clarify which approach the author uses in describing the interpreters' views.

Dockery (1988) explains the difference between exegesis and hermeneutics:

Exegesis seeks to account sufficiently and adequately for the historical and literary features of the text in its context. Hermeneutics on the other hand is an attempt to understand the meaning of the text for the contemporary readers ... (p. 139)

In terms of the explanation above, the author will draw from selective theologians' responses on their interpretation, and what the text should mean for contemporary readers. Therefore, what does Jesus' meeting with the Samaritan woman mean to contemporary readers and for theologians? This is indeed determined by what I refer to as the choreographers' interpretation of the narrative in John 4 - not an exegesis which explains the intentions of the original author, or his or her original audience, but what authors convey as the contemporary understanding of this text; of the movements of the two conversation partners.

In terms of a theological reflection, I will focus on particular authors whose views on this woman may be more liberating than those which bound women to the stereotypical and patriarchal perspectives that are often the case. Therefore, the work of Spencer (2004), and also of others, is part of the material that will be discussed. However, in contrast to the aforementioned scholars' view, the author engages interpretations of the John 4 text that are still accommodating views and reconstructions of the biblical text which reflect a patriarchal perspective on and reading of the text. It will also be quite interesting to weigh this up against the responses from those who are in the context of homelessness, and will have to respond from their own context to the text in relation to the reality of gender-based violence.

How do theologians describe the dance? I will now draw on scholars such as Spencer (2004) and Kim (2004) as well as others who provide their commentary on the woman at the well. With regard to the John 4:1-42 text, Kim (2004) writes:

A text produced within a patriarchal society not only derives from a male point of view, but also presents the male view as normative to all those who read the text, whether the readers are 
male or female. Since the so-called normative nature of the text has long gone unquestioned, there is no question but that a feminist biblical approach should criticize the sexist ideology of the text. (p. 91)

\section{Theologians' choreography of the dance}

Spencer (2004) substantiates why he believes that the disciples must have been shocked at least at Jesus' approach, his conversation and meeting with a woman at a well. He argues that it was not about Jesus' speaking to a woman in public, but rather previous associations and incidents which happened at wells and which were documented in the Bible. Interpreters will often refer to it as the 'betrothal scenes'. Spencer refers to some of these scenes, such as the meeting between Abraham's servant who arranged for Isaac's marriage with Rebecca (Gn 24:10-61), Jacob who kissed and wept for joy over Rachel (Gn 29:1-14), as well as the moment when Moses impressed Zipporah who would become his wife. Indeed, some good love 'affairs' happened at wells, in which some of our great biblical ancestors were involved. Therefore, his conclusion, that the meeting between Jesus and the Samaritan woman at least reminded the disciples of how the ancestral fathers behaved at the wells. He implies that the disciples and choreographers of this text should focus on the possible suspicion that there might have been from the disciples; on the 'initiative' that Jesus took at the well. Because, he reasons, history could have reminded them of what eventually happened when Jewish men met women at a well. He therefore raises the argument quite convincingly that they might have been suspicious of their master also being part of a 'love affair' at the well in Samaria.

Despite such a possibility, most male theologians, as will be pointed out later, choreograph the 'movements' between Jesus and the Samaritan woman in a way that does not raise such an argument - and certainly does not present Jesus as one who will engage in a 'love affair'. In contrast to this portrayal, most choreographers present the woman with suspicion over her 'love life' in the narrative when they describe her movements in relation to the movements of Jesus. It is quite interesting to note how Spencer would focus on Jesus' movement as the one who made the 'first ... bold ... personal move' to solicit 'the woman for a drink to pass through his lips and into his body' (Spencer 2004:88). This is quite creative, and it is not impossible to suggest such an interpretation, at least not in modern-day society with men's approaches and similar pickup lines to women. Kim (2004:98) also engages the 'betrothal scene' idea and in a very creative way states the following: 'The dialogue begins with Jesus' request for water. The Samaritan woman's response (4:9), however, shows that the dialogue between them is not like the betrothal-type scene in which the woman is submissive or silent in response to the man's request'. Therefore, Kim states that the woman acts unlike the conventional betrothalscene narratives, and credits the woman for her courage, and 'agency' in the John 4 narrative.
Spencer (2014) also cautions the conventional explanation of the 'timing' of the Samaritan woman by interpreters that the woman might have been an outcast, as a result of her 'adultery' and therefore she did not want to meet other women at the well, and chose a time when she would have been alone at the well. However, Spencer does not entertain such an interpretation - which would, again, put the status of this woman in jeopardy against her male counterpart in the narrative. Therefore, his interpretation is based on a socio-historical observation: '... the Samaritan's workload might have required multiple trips to the well' (Spencer 2004:88). This kind of interpretation lends itself to refer to the 'industrious' nature of this woman - being a hard worker and a contributor to the 'economic' welfare of her dependants in Samaria. Malina and Rohrbaugh (1998:98), referring to the time that the woman went to the well, argue that the work of women in ancient Mediterranean times often included the responsibility to 'fetch water for the household'. Although their argument above does not specifically refer to the 'timing' issue, as their choreography is not 'woman-friendly', it supports the argument of Spencer on the 'industrious' nature of women (including the Samaritan woman in the narrative).${ }^{8}$

There is equally less evidence for the first interpretation than the latter, but it is quite often a convenient argument to opt for the first one - framing the woman as inferior in her position. In fact, it is contrary to most interpretations of the status of the woman, brushing her with suspicion, while Jesus as a 'male embodiment' himself credits the woman as one with integrity, character, someone who can be trusted, when he states reverberatingly: 'Thy have well said I have no husband' (v.17). Malina and Rohrbaugh's (1998:99) argument is in contrast to that of Spencer (that the man started with a pickup line); rather they argue that this woman does not even protect her 'sexual exclusivity'; therefore, it could be assumed that she is an adulteress or a 'mistress'. They (1998) state the following:

That she decides to report a conversation about her own sexual behaviour, however, is strange indeed. It suggests she feels no obligation to defend or protect her sexual exclusivity. She appears to be either an adulteress or a 'mistress,' a fact that the author presumes to have been known to her audience. Her positive shame, her honor status, was thus beyond retrieval. In any case, such talk in public between unrelated men and women about sexual matters goes far beyond cultural expectations. Not only this, but in her report she indicates that she had been doing the same thing (talking about sexual matters) with a total stranger to their neighborhood (Jesus)! (p. 99)

Kim (2004:106) rejects the notion that the woman is often classified as a 'sinful' woman and argues that within the socio-historical context in which the Samaritan women found themselves, they were 'sexually exploited or marginalized's

8. It is clear in the interpretation of Malina and Rohrbaugh (1998) on the John 4 text that the kind of 'choreography' of the text that they present is not 'woman friendly'.

9.For instance, the 'decision to divorce was mainly a male prerogative' (p. 106) women often employed the strategy of 'voluntary rape' to avoid ongoing 'brutal border during wartimes' (p. 105). 
in colonial periods, and that this woman is part of a patriarchal power game between nations, both literally (men or women) and symbolically (coloniser or colonised). Day (2002:7-40) analyses the way in which the church, throughout the ages, has interpreted the passage of the Samaritan woman and Jesus at the well. It is interesting to see how Day (2002:18) highlights the way the church fathers interpreted this woman as 'both apostle and evangelist, in comparison with whom the male apostles and disciples are found to be less effective'. Day (2002) also refers to Byzantine hagiographers that claim:

... she received baptism at Pentecost along with her five sisters and her two sons. She then began a career as an itinerant missionary, travelling far and wide to proclaim the gospel. (p. 18)

Day argues that there seemed to be an alteration in interpretation during the Reformation period; picking up on Luther's comment on the woman as follows: 'Apparently she was not a bad woman. Still she is reluctant to give Him water' (2002:20). Day (2000) also frowns upon the interpretation and remark of John Calvin, labelling the woman as a prostitute:

to preach about the grace and power of His spirit, and that to a hussy who did not deserve Him to speak to her at all ... For what was there in this unhappy woman, suddenly from a prostitute she became a disciple of the son of God? (p. 21)

According to Aquinas (2010:2011), the issue of 'time' is twofold. It can refer to the physical time to provide reasons why Jesus could have been tired, but also to the spiritual time - the time that has come for the salvation of many on the earth. Aquinas also goes to great length to spiritualise the issue of 'water' - 'because he thirsted for the salvation of man on account of his love' (Aquinas 2010:211). There is indeed nothing per se wrong with such an interpretation - only that it chooses not to be satisfied with a 'literal' meaning of the text - which would have been liberating to women in oppressive, patriarchal societies. Instead, the interpretation of Aquinas provides space in its interpretation for the argument - that because she is 'sensual' and she could not understand what the Lord meant in a spiritual sense (Aquinas 2010:217). Spencer (2004:89) underlines what he refers to as the male Jesus' aim in the conversation - to focus on 'right knowing'. It is about 'who knows what about whom' between the male Jesus and the woman. Spencer reminds his readers that the issue of knowledge is quite important in femalemale ${ }^{10}$ conversations. Spencer (2004:89) frames Jesus' quest into what the woman knows, in the context of the 'male goal'. He argues that men's goal of 'know-why know-how' is ultimately to say: 'I know how you feel...' which, at least for those men, would put them in a 'one-up' position in relation to women. It is therefore striking that 'choreographers' of this text focus so strongly on how Jesus corrected the woman on 'religious matters', whereas less are being said about the 'details' she knew about her own religion. It is indeed enough to keep the conversation going, or should I say - to keep the 'dance' going. She made a good 'dance partner' - clever and intellectually up to scratch to keep her movements in step with what is about to unfold in bringing the performance to 10.It is quite interesting to note how Spencer $(2004: 89)$ uses the order of womanman, and not the other way around. its climax. How the 'knowing' of the woman is interpreted against that of her male counterpart is important, as it would indeed feed into the broader and external narrative of the supremacy of men, because they are often socially perceived as having higher cognitive abilities than women, especially when it comes to religious matters. The latter interpretation (men having higher cognitive abilities) would indeed strip the Samaritan woman as leader, and her agency in the 'dance' - to give the cue for the next step in the performance.

Maccini (1996:119) refers to the woman as one who goes through a process 'in which she moves from a shallower to a deeper understanding of who Jesus is'. In fact, in terms of Maccini's statement, it seems that her good capabilities are rewarded. The question is, by whom? It is indeed clear when one further analyses Maccini's commentary that less credit in terms of religious knowledge is given to the woman in the narrative. Maccini (1996:134) reveals his disagreement in reference to the argument of Sophia Scott: 'This woman seems to know something and to be prepared to discuss it openly, with a male Jew'. It is evident that 'dancing' with Jesus is not easy, especially when women should only respond to the 'movements' and not be responsible for taking the lead in the 'dance'. This is clearly not what Jesus (in his divinity) is doing. However, Jesus gave the woman the opportunity to be liberated from the stereotypical thinking of a patriarchal society in which women are to be always suspected of 'suspicious' acts, and cannot be trusted, but his affirmation that she is 'telling the truth that she does not have a husband' is giving her the 'benefit' of all doubts, which should be emphasised in the interpretation of the text. The way this woman made it almost too easy for Jesus to converse, and to 'dance' is evident, because she knew a lot about the 'religious tensions' between the Jews and Samaritans, and she was able to be a good partner in the dance. The words from Malina and Rohrbaugh (1998:99) in sum do not really provide a useful interpretation, but provide some insight that still allows us to reflect positively on this woman when they refer to the woman's truthful response and Jesus' praise thereof. Jesus as a 'maleembodiment' is also breaking away from such conventional male behaviour, as well as the norms ascribed to most men in a patriarchal society. That is why Spencer argues that the behaviour of Jesus, as the Messiah, differs from conventional male behaviour. Spencer (2004:91-92) highlights that in the midst of such female-male relations and conventions:

Jesus breaks the stereotype; here the man uses his knowledge not to dominate but to communicate, not to erect an empire but to create a bond with an engaging woman. (pp. 91-92)

What is also quite salient in Spencer's words is that he cautions, 'Jesus makes no judgement about this woman' (Spencer 2004:91). In final view of this story, Spencer (2004:92) states, 'Jesus both exhibits and explodes stereotypical patterns of male discourse'.

It is noteworthy that some 'choreographers' will not focus on the 'gender' tendencies in the text, but focus entirely and for 
their own reasons on the 'religious tensions' between the Samaritans and the Jews. One such interpretation is that of a contributor to an esteemed commentary interpretation on the book of John. Sloyan (1988) emphasises what he believes is the main purpose of the John 4 narrative:

Hence all moralizing about the woman's irregular life and Jesus' relations with women, interesting as they are, are not especially useful as an exposition of the text. The story is about religious tensions and a church, which, in its origins, sought to overcome them, even while the attempt itself caused new tensions. John 4 should be preached in the spirit in which it was written. If it is not, the Gospel is betrayed. (p. 51)

The blatant rejection of the value that such an interpretation, focusing on women's irregular life and Jesus' relation with women, is one of the reasons why issues of patriarchy and women's suffering are not taken seriously. In fact, such an interpretation of the text seems to suggest that it is not worthy of spending endless time on 'who is who' and 'for what purpose' in the narrative. It is often noted that it is for such choreographers of this narrative about the 'outcome', not the woman as a 'smart' 'intellectual'; fitting conversation partner. In fact, for Sloyan (1988:53), the main point of the narrative is 'Jesus' superiority to Jacob in all respects (v.12), as well as his promise of a spring of water that wells up to eternal life (v.14). Although this could not be ignored, the contribution in the whole story, bringing to the fore in our interpretation the 'movement' of the other dancing partner, is equally as important as the 'outcome' and contribution of the male partner, Jesus, the Messiah in the narrative. Malina and Rohrbaugh (1998:98) argue that the woman is astonished because of her native (Samaritan) as well as her gender (female) and Jesus is both a male and an outsider. They state: 'Such awareness of gender and origin was quite typical of social interaction in antiquity' (1998:98).

Kim (2004:109) also asserts that this passage is about gender, and can clearly be observed in the words of the disciples when they came back as a 'woman from Samaria' as well as the woman herself referring to her as a 'Samaritan woman'. Kim asserts that John uses Greek feminine words for Samaritan, which 'show that the female nature of the woman is emphasized, through which we can assume that the ethnic matter is not as important as the gender matter'. Maccini (1996:133), on the other hand, believes that what dominates this narrative then is not the relationship between men and women but between Jews and Samaritans - because the woman's astonishment was a religious one: 'Why a Jew' asks her water.

Besides the efforts of Spencer, arguing for a 'womenfriendly' interpretation, I would like to present some other commentators' remarks that highlight the woman's steps in the 'dance'. Maccini (1996:121) wrestles with the words or question of the Samaritan woman in verse 29: 'could He be the Messiah?' While some commentators would say she might have doubted and needed advice, Maccini seems to agree with those commentators who see her question rather as a 'strategy' used to convince the villagers. Maccini (1996:121) states, 'She is careful not to state the incredible [that Jesus is the Messiah] outright'.

Kim (2004:98-99) critiques John's presentation of Jesus' omniscience and the woman's ignorance and states, 'John never allows the Samaritan woman to grasp the meaning of Jesus' words but simply uses her ignorance or misunderstanding to progressively reveal Jesus' identity'. This rhetoric of John, she argues, '...makes the Samaritan woman into an unimportant 'other' by seeking to silence her, with her only purpose in the narrative being the revelation of Jesus' identity'. Kim (2004:99) refers to this as 'victimisation'. Kim refers therefore in relation to this, to how the woman is asking questions and Jesus not directly answering her, and Jesus offering her water (4:10) 'without asking if she needs it or not'.

In terms of the witnessing of the woman, Kim (2004:110) argues that John is diminishing her role in the salvation of the Samaritans, because it was she who told Jesus of her people's confession of Jesus as the 'Savior of the world'. Kim (2004:110) states, '[John] Highlighting the contrast between the woman's words and Jesus' words (4:39-42), John diminishes the woman's contribution to the advancement of her people's confession of Jesus as the Savior of the world'.

However, it is quite interesting, when comparing Spencer and Kim (as some of the theologians providing a womanfriendly interpretation) with other theologians' interpretations on the John 4 narrative. For instance, for Sloyan (1988:54), the focus is on the woman as a representative of the 'Samaritans' - a conversation that has at its heart the 'religious tensions'. However, what about this woman being a representative of women? Therefore, Sloyan, unlike Spencer, does not place an emphasis on the 'gender' of the discussants, although there is one instance where Sloyan (1988:54) focuses on the status of this woman in her society: 'The female member of a people despised by Jews is provided with a disorderly life (vv.16-18) to make her trebly a minority person: woman, Samaritan, polygamist'. In spite of this remark, not much is said about her agency in the evangelisation of her fellow Samaritans. The interpretation of Sloyan, if not careful, could lend itself to the notion that females are only co-opted in males' agenda and do not possess self-agency in the mission of God. Malina and Rohrbaugh (1998) refer to her witness not only in public space, but also in 'male space'. They assert:

If she has gone to the place in town where people are normally gathered, that is, to the public square, she is decidedly in public, male space. She had been told to go back to private space (her husband), but she goes straight to the most public space available. With no hesitation whatsoever, the woman tells the men about her conversation with Jesus. (p. 101)

Furthermore, in Sloyan's (1988) interpretation, it is more about 'Who Jesus is' for the Samaritans, and also how Jesus played a significant role in bringing these two nations (i.e. Samaritans and Jews) closer to one another throughout 
his conversation with the woman of Samaria. Sloyan (1988:58) describes Jesus as the 'reconciler of ancient enemies'. He (1988) states:

Common work in common causes - the relief of the needy, the living of the gospel - is best of all. Yet the healing of old divisions needs to be kept to the fore constantly. It is part of the preacher's office. It is the main concern of John 4. (p. 58)

There is certainly no room in his interpretation for the role of the woman in 'reconciling ancient enemies'.

While Kok (2016:3) has much to say about Jesus who challenges the patriarchal system of the day, he still suggests the following interpretation, which differs slightly from Spencer's interpretation of Jesus' move on this woman: 'After Jesus reveals to her that he has revelatory information and/or knowledge about her life, and she opens up to him, he offers her true spiritual life'. Spencer, as stated earlier, saw this in quite the opposite way: a male figure showing off about 'what he knows', to immediately put him in an advantageous position over the woman. It does not quite do justice to the 'illumination' of the role of women in the broader spectrum, whether the 'evangelisation of Samaria', or the 'grasping of her knowledge of the eternal life on offer'. In terms of Spencer, it is equally the woman's role in the conversation and in the entire narrative that lead to the most ultimate and wonderful performance by two 'dancing partners'. ${ }^{11}$

It is Aquinas (2010:211) who refers to the weakness of Jesus. He argues that John showcases the weaknesses of the human body - besides Jesus being God and has unlimited power. Aquinas really gets to the 'humanity' (limits of the human body - to get tired and thirsty) aspect in his commentary on Jesus - but not enough to reveal the 'gender inequalities' the text might refer to. In fact, when Aquinas comments on the woman, he immediately 'spiritualises' the woman to signify the church.

Let us now turn briefly to the interpretation of the homeless group and how they describe the 'movements' between the two male and female discussants in terms of both of them their role, status and position in the conversation.

\section{The homeless people's choreography of the 'dance'}

In the homeless group's choreography of the text, there are instances where it still reflects gender stereotypes, and patriarchy in the way the biblical text in John 4 is interpreted. How did they reflect on Jesus as a 'dancing' partner? They reflected in some cases on Jesus' 'respect for the woman' - his acceptance of the woman 'without judgement' and his character as that of 'humbleness, peaceful and love'.

Furthermore, Jesus is seen as the 'Hero' because 'he is the one she met' (which I did not fully understand as the meaning behind this statement), and for them 'Jesus is the leading character', who is in particular 'leading the woman'. Jesus is reflected through their responses as the one who 'brought salvation [to the woman] - then [the] woman to others'. Jesus was the leading character because, as they argued, he was 'sent' (by God). But, is it only 'men' who are sent by God? Could the woman not also have been sent by God, with Jesus fulfilling the missio Dei? What were the role, positions and status of the woman for them? The participants argued that the woman was a 'messenger', a 'witness'.

The contention is that one or two participants reported, after some discussion and a little bit of effort from the facilitators, on the role of the woman - they agreed that the 'woman is leading' the conversation, and furthermore, that the 'Lady started the conversation, Jesus only asked for water'. A greater insight into the role this woman played in the narrative is underlined by another response from them: 'The Samaritans got saved because of the Samaritan woman's salvation and her meeting the Messiah'. Maccini (1996) would agree with them that she was a witness for the salvation of the villagers in Samaria:

A Samaritan woman came to draw water. But she did so much
more. She encountered at the well a stranger having miraculous
knowledge whom she recognizes as a prophet and perhaps more
than a prophet. On the strength of her testimony, her fellow
villagers made their first steps toward what eventually would
become their recognition of Jesus as the Savior of the world ...
Her testimony, as far as it goes, is true. Samaritan, Jewish or
other, it is not difficult to imagine John's readers, like the
villagers, accepting her testimony and coming out to meet Jesus
for themselves. (p. 144)

The participants also described Jesus as the one who 'saw that the woman is willing to tell the truth'. However, it should be stated that during the Bible study, the participants raised this issue, very hesitantly, with suspicion of the woman - that she was likely to have some 'skeletons in her closet' and now 'she was willing to tell the truth'. However, it is strange that nothing was said by the participants on the affirmation of her integrity by Jesus, and that she was a woman of character, who would tell the truth even without those who knew her story, in the immediate vicinity. It should have been easier for the woman to lie. One could raise the questions: Was Jesus really in control of the conversation? Was Jesus really leading the 'dance'? Or was she just pushing the right 'buttons' for the next step?

What is indeed interesting is their reference to Jesus as the one who will ensure that the 'woman will reach her destiny (eternal life) - if she sticks with what Jesus gave her'. Why should she stick with Jesus? She did not stick with Jesus; she went in the village on her own to tell them about the man she has met, and that he has revealed some things about her, and that he must be a prophet. Jesus never took her agency away as suggested by the homeless group's choreography of the narrative. Maccini (1996:134) refers to Boers: 'She is Jesus' co-worker in an unprecedented way, more concretely even than John the Baptist'. 
Much more interesting is their reference to Jesus' determination, which is not picked up through one's reading of theologians' choreography of the text. Therefore, this is quite ironic as it indeed positions Jesus as the leading partner in the 'dance', which should keep control of the conversation and outcome at all times, before anything goes wrong (?). Though there is not such an explicit reference in the text to substantiate that we could interpret that Jesus was determined, it is clear in the text that Jesus was only confirming most of the 'revelatory' details brought forth by the woman herself, rather than him being determined at all.

The participants also stated, 'Jesus asks the woman water and the woman denied and refused'. However, as a response, it is arguably so that this would be what most women would do, especially a woman who keeps her morality intact, not to give water to a stranger, a man who is not her husband. She kept her position quite well, in what most people today would say, 'She was a woman who was not grabbing the opportunity to "score" some points or to win the favour of a man who seems to be single, and "available".

The homeless group's responses are also positioning the woman as the one who does not 'know'. They responded, 'Jesus says things the woman knew not', 'the Samaritan woman did not know when the Messiah was coming' and the 'Samaritan woman was thirsty, and she did not have knowledge ...' However, it is strange that they did not mention that the woman was not entirely clueless or sitting with sealed lips. On the contrary, she knew how to keep the conversation going and she was never without an answer.

Why should the homeless group be suspicious of the woman by responding: 'she thought he is chatting [flirting] with her'. It is quite strange that the man, who made the first move, is not questioned. It could be well argued that they regard him as Jesus, the Son of God, whose motives were at all times pure. He would never be suspected of wanting to make a 'move' on this woman. Is this not a convenient argument, because there is not much thinking going into it, to accuse the woman in the narrative of a 'carnal mind' or having 'ulterior motives' to seduce the tired man who is sitting at the well? ${ }^{12}$

What was quite disturbing in the responses of the homeless group in terms of the status of the woman is that they labelled her as one with a 'carnal mind'. Is it not reasonable to argue that everyone can get confused if someone is mixing the conversation with 'literal' and 'figurative speech' without indicating it as such? This can happen to anyone, because it was never said to be a 'spiritual' conversation. By the way, was Jesus' first request for 'literal' water not 'carnal'?

However, credit should be given when some responded, in terms of the specific question on how the text refers to gender-based violence, that 'wisdom is necessary to approach 12.In fact, modern readers would know how easily tired men can be seduced; why not pull out such an interpretation on the male conversant? sensitive things', but also that 'both genders need each other'. Although the above responses do not fit in quite well with their interpretation of the text, it is noted that there is indeed an effort to promote the full humanity of both male and female genders in society.

\section{Getting off from the dance floor}

I use the metaphor of dance in this article especially because choreographers of the text, whether ordinary readers of the text or scholars serving as choreographers, ${ }^{13}$ describing the human, physical movements between male and female characters in biblical texts, promote the full humanity of both men and women.

Patriarchy has always been the cause of the relegation of women to an inferior position. This is seen in the way especially male theologians, and a large section of the homeless people, would interpret the text in question. It should be noted that there was indeed tension in terms of the 'status' and the 'role' of the woman. It reflects the same kinds of tension that exist among theologians, in terms of the position, status and the focus that is placed on the woman within the literary context.

I find the view of Surekha (2007) valuable and insightful in this regard:

In most of the readings, Jesus was typically seen as the giver, the liberator, the one who reached out to the needy, and the emancipator, as opposed to the Samaritan woman, who is presented as a receiver. This perspective exemplifies the patronizing aspect of liberation even in feminist and other contemporary readings. Such a model of liberation maintains marginalization and hierarchy, where one is considered as a giver and the other as a receiver. Although it is a comforting and hopeful interpretation of Jesus as emancipator of women, this reading supports the traditional hierarchical tendency, placing Jesus in a superior 'giver' position and maintaining the power disparity between Jesus and the Samaritan woman. Is Jesus truly a giver in the context of the story? Was he absolutely self-sufficient when he approached the Samaritan woman? Was he not in a need of a drink? (p. 2)

Pillay (2015:559) alerts us to the 'subtle and obscure patriarchal power in marriage, family, church and society ...'. This was mostly evident in the communal and contextual reading with a group of homeless people in the City of Tshwane. It was evident in the way these participants interpret the biblical text. It was done in a way that reflected the stereotypical and patriarchal interpretations.

It is indeed surprising to note how the homeless people who formed part of the contextual Bible studies, and who were on a daily basis marginalised by nature of others' perceptions of them (as they were not able to positively contribute to the welfare of society), would also act as oppressors. After all, they would not be able to respond in a way that is liberating

13.1 bring the 'ordinary readers' of the text in conversation with the 'trained' readers (theologians). West proposes this as part of his method of CBS that I used as a method in this article. 
towards others who share their experience of oppression, marginalisation and stigmatisation. In their interpretation, it shows how they 'choreographed' these movements between the man and the woman, which still reflects a stereotypical perspective on a woman's role, status and position in society, which belongs to the patriarchal narrative that most people who endorse gender-based violence ascribes to. This kind of reading of biblical texts still serves as a cause for the oppressive and violent acts that abounds in the very city (Tshwane) in which they live.

\section{Conway (1999) argues in sum that:}

the Samaritan woman is presented as a practical, bold, and tenacious woman, one who not only holds her own in conversation with Jesus, but drives the dialogue forward with her own thoughtful questions and observations. The result of the woman's persistent engagement with Jesus is a dawning realization of his identity on her part that eventually leads to the conversation of her people. In this way the woman moves from a mere conversation partner to a partner in Jesus' ministry. (p. 125)

Kim (2004:91) critiques the sociopolitical dimension in terms of the role of the Samaritan woman, and argues that she gradually diminishes (4:41-42), and 'finally disappears altogether from the Johannine narrative' (4:43). Therefore, Kim (2004:91) argues that it is not clear 'to what extent the text supports the woman's role as missionary or as an exemplar of faith'.

The issue of a false consciousness is what is at play in the responses of the homeless group, that some of them were and are currently suffering oppression - simply by what it means (in terms of position, status and role) to be a woman, being black, marginalised, homeless, not having a voice and not even written into the City of Tshwane's success stories, only because of their social identity. The strange thing is that they have come to accept this as a social reality and construction of the world, which is often derived from theirs, as well as others' interpretations of biblical texts, including the church. However, their positive contributions in terms of gender equality, for instance, when they reported 'both genders need each other', should encourage others.

\section{Ethical considerations}

All the participants of the research gave written consent for ethical clearance.

\section{Conclusion}

An analysis of scholars' interpretations and that of homeless people clearly shows that metaphorically dancing with Jesus is not easy - especially when a woman is the dancing partner and is choreographed by male theologians. But it is also not easy when women are still shown in the reading and interpretation of a homeless group being given the roles, status and positions that reflect 'subjugation', 'discrimination', 'inferiority to men' and 'co-option without agency' as what has often been the case in a patriarchal society. It is sad that this is still the social reality, and that the church is still framing and choreographing women in such a way. This is the reason that women are not being valued and treated with the same humanity and dignity as their male counterparts. Jesus was liberating the Samaritan woman in the text, while some choreographers are still to follow. As long as the interpretation and choreographing of the movements between male and female characters in biblical texts are not 'woman-friendly' and choreographers are not committed to liberate women from oppressive biblical interpretations, it will not be easy to deal with gender-based violence in our societies.

\section{Acknowledgements}

The article emerged from the 'meal of peace' community engagement project of the Department of Christian Spirituality, Church History and Missiology at the University of South Africa. The author acknowledges the participation of the group of homeless people in the City of Tshwane, South Africa.

\section{Competing interests}

The author declares that he has no financial or personal relationships that may have inappropriately influenced him in writing this article.

\section{Funding information}

The study was funded by the Department of Christian Spirituality, Church History and Missiology at the University of South Africa.

\section{References}

Ackermann, D.M., 2003, After the locusts: Letters from a landscape of faith, Eerdmans, Grand Rapids, MI.

Ackermann, D.M., 2005, 'Engaging stigma: An embodied theological response to HIV and AIDS', Scriptura 89, 385-395.

Ackermann, D.M., 2006, 'From mere existence to tenacious endurance: Stigma HIV and AIDS and a feminist theology of Praxis', in M.N. Pillay, S. Nadar \& C. Le Bruyns (eds.), Ragbag theologies: Essays in honour of denise Ackermann: A theologian of Praxis, pp. 221-242, Orbis Books, Maryknoll, NY.

Aquinas, T., 2010, Commentary on the Gospel of John, chapters 1-5, transl. F. Larcher \& J.A. Weisheipl, Catholic University of America Press, Washington, DC.

Conway, C.M., 1999, Men and women in the fourth Gospel. Gender and Johannine characterization, SBL, Atlanta, GA.

Day, J.N., 2002, The woman at the well. Interpretation of John 4: 1-42 in retrospect and prospect, Brill Publishers, Leiden.

Dockery, D.S., 1988, 'Reading John 4:1-45: Some diverse hermeneutical perspectives', Criswell Theological Review 3(1), 127-140.

Karim, Q.A \& Baxter, C., 2016, 'The dual burden of gender-based violence and HIV in adolescent girls and young women in South Africa', SAMJ 106(2), 1151-1153. https://doi.org/10.7196/SAMJ.2017.v106i12.12126

Kim, J.K., 2004, Woman and nation. An Intercontextual reading of the Gospel of John from a postcolonial feminist perspective, Brill Academic Publishers, Boston, MA.

Kok, J., 2016, 'Why (suffering) women matter for the heart of transformative missional theological perspectives on empowered women and mission in the New Testament and early Christianity', HTS Theological Studies 72(4), 3519. https:// doi.org/10.4102/hts.v72i4.3519

Landman, C., 2006, 'Can justice be embodied in sexist language? A challenge to the confession of Belhar', Ned Geref Teologiese Tydskrif (NGTT) 47(1, 2), 283-290.

Maccini, R.G., 1996, Her testimony is true. Women as witnesses according to John, Sheffield Academic Press, Sheffield.

Malina, B.J \& Rohrbaugh, R.L., 1998, Social science commentary on the Gospel of John, Fortress Press, Minneapolis, MA.

Pillay, M.N., 2003, 'Church discourse on HIV/AIDS: A responsible response?', Scriptura 82,108-121. https://doi.org/10.7833/82-0-902 
Pillay, M.N., 2005, 'Luke 7: 36-50: See this woman? Towards a theology of gender equality in the context of HIV/AIDS', Scriptura 89, 441-455. https://doi.org/ $10.7833 / 89-0-1029$

Pillay, M.N., 2007, 'Christian in public: Aims, methodologies and issues in public theology', in L.D. Hansen (ed.), Re-reading New Testament texts: A publictheological resource for addressing gender inequality in the context of HIV/AIDS in South Africa, pp. 209-226, African SUN Media, Stellenbosch.

Pillay, M.N., 2013, 'The Anglican Church and feminism. Challenging "the patriarchy of our faith"', Journal of Gender and Religion in Africa 19(2), 53-71.

Pillay, M.N., 2015, 'The church, gender and AIDS. What's wrong with patriarchy?', Missionalia 43(3), 558-567. https://doi.org/10.7832/43-3-130
Sloyan, G., 1988, Interpretation. A Bible commentary for teaching and preaching. John, John Knox Press, Louisville, KY.

Spencer, F.S., 2004, Dancing girls, loose ladies, and women of the cloth. The women in Jesus' Life, Continuum, New York.

Surekha, N., 2007, Jesus asks the Samaritan woman for a drink: A Dalit feminist reading of John 4, viewed 28 September 2018, from http://www.lectio.unibe. ch/07_1/pdf/surekha_samaritan_woman.pdf.

West, G., 1993, Contextual Bible study, Cluster Publications, Pietermaritzburg.

Wikipedia, 2018, Dance, viewed 28 September 2018, from https://en.wikipedia.org/ wiki/Dance 